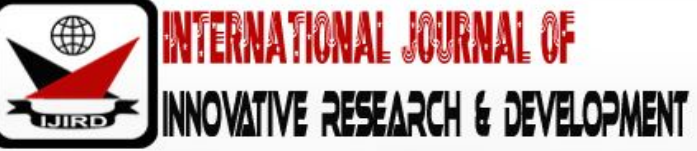

ISSN 2278 - 0211 (Online)

\section{Bumiputera Parental Support in Chinese Primary School Selection in Malaysia}

\author{
Dr. Mohamad Iskandar Shah Sitam \\ Faculty, Department of Centre for Education and Community Well-Being \\ The National University of Malaysia, Malaysia \\ Abdul Razaq Ahmad \\ Professor, Department of Centre for Education and Community Well-Being \\ The National University of Malaysia, Malaysia \\ Mohd Mahzan Awang \\ Associate Professor, Department of Centre for Educational Diversity \\ The National University of Malaysia, Malaysia
}

\begin{abstract}
:
This study aims to identify Bumiputera parental support in Chinese primary school selection in Malaysia from the aspects of family, local community, school reputation and career potential. Sample of the study consisted of 720 Bumiputera parents whom send off their children to 18Chinese primary schools in Sarawak state, Malaysia. Pilot study results based on Cronbach's Alpha analysis revealed that all items in the overall constructs is at high reliability level between0.92 and 0.95.data were analysed using SPSS 22.0 involving descriptive and inferential analyses. Findings show that career potential and school reputation were the main factors in school selection and reported to be at moderately-high levels. Meanwhile, MANOVA analysis illustrated that there were significant differences for the aspects of family, local community, school reputation and career potential based on parents' socio-economic status. Implications of the study show that knowledge and environment related to social provide great influence on parents' decisions in determining their children's future education. Hence, any information on school reputation is ought to be focused on by all parties to enhance stakeholders" confidence regarding academic excellence in their respective school.
\end{abstract}

Keywords: Chinese primary school, school selection, Bumiputera parents and pupils

\section{Introduction}

Chinese primary school is one of vernacular school types as introduced by the British occupation in Malay land. Since Malaysia gained its independence in 1957, this type of schooling continues its operation until present time using their mother tongue as main medium for teaching and learning (Khoo Kay Kim, 1998).The overall total of Chinese primary schools is 1250 and 2211 in Malaysia and Sarawak respectively (Tan, 2010). This situation shows demands of enrolling children into Chinese primary school is growing particularly among Chinese community. Nevertheless, other communities also prefer to send off their children to get education in Chinese primary schools. Yair (1996) \& Cooper (1991) finds out that the tendency of education selection is mainly influenced by environment and school reputation. Tan (2010) revealed that Chinese schools students have higher chances in career as compared to students from other schools due to their competencies in Mandarin, Malay and English languages. Besides that, majority of Chinese community in Malaysia get involved in businesses whether insmall enterprises like grocery, or large scale industries like construction which results in favouring candidates with Mandarin proficiency (Malay Mail, 2012). Lee\& Khalid (2013) revealed that students with Mandarin language abilities have higher chances of getting called for interview by Chinese-based and international companies in Malaysia. Number of other ethnicities whom prefer to enrol their children in Chinese primary schools escalates year by year whereby 67,128 which represents $12.6 \%$ other ethnicities enrol their children in Chinese primary school in 2016. Similar situation also can be observed in Sarawak and it is found that there are limitations of studies relates to Chinese-based education and merely to be reported via newspaper articles. Hence, a comprehensive and empirical study is ought to be conducted to identify the factors influencing the parents' decision in choosing Chinese primary school as the place for the children to gain knowledge and education.

\section{Aims of the Study}

This study aims to identify Bumiputera parental support in Chinese primary school selection in Malaysia. Besides that, it also aims to investigate the level of Bumiputera parental school selection support for every aspects including family and local community, school reputation and career potential. 


\section{Methodology of the Study}

This survey study utilised questionnaire as the main instrument for data collection. Sample of the study consisted of 720 Bumiputera parents whom send off their children to 18 Chinese primary schools in Sarawak state, Malaysia. The Bumiputera consisted of several tribes namely Melayu, Iban, Bidayuh, Melanau and Orang Ulu. Prior to data collection, a pilot study was conducted to validate the items and the results based on Cronbach's Alpha analysis revealed that all items in the overall constructs is at high reliability level between 0.92 and 0.95 .

\section{Findings}

\begin{tabular}{|c|c|c|c|}
\hline Item & Mean & Standard Deviation & Interpretation \\
\hline Family \& Local Community & 2.98 & 0.52 & Moderately-Low \\
\hline School Reputation & 3.17 & 0.76 & Moderately-High \\
\hline Career Potential & 3.46 & 0.84 & Moderately-High \\
\hline
\end{tabular}

Table 1: School Selection Support

Descriptive analysis shows that Chinese school selection support for the aspects of family and local community is at moderately-low level (mean $=2.98$ and standard deviation $=0.52$ ). Meanwhile, for the aspects of school reputation $($ mean $=3.17$ and standard deviation $=0.76)$ and career potential $($ mean $=3.46$ and standard deviation $=0.84)$ are at moderately-high levels.

\subsection{Chinese School Selection Support for the Aspect of Family and Local Community}

\begin{tabular}{|c|c|c|c|}
\hline Statement & Mean & Standard Deviation & Interpretation \\
\hline I choose Chinese school because of my children's preferences & 2.79 & 1.34 & Moderately-Low \\
\hline $\begin{array}{c}\text { I choose Chinese school because my children wants to be friend } \\
\text { with Chinese }\end{array}$ & 2.87 & 1.39 & Moderately-Low \\
\hline I choose Chinese school because of my own will & 3.07 & 1.39 & Moderately-High \\
\hline I choose Chinese school because of my relatives' suggestions & 3.09 & 1.41 & Moderately-High \\
\hline $\begin{array}{c}\text { I choose Chinese school because many of my relatives send their } \\
\text { children to this school }\end{array}$ & 2.87 & 1.39 & Moderately-Low \\
\hline I choose Chinese school because of my neighbours' suggestions & 2.65 & 1.31 & Moderately-Low \\
\hline I choose Chinese school because of my friends' influences & 3.25 & 1.33 & Moderately-High \\
\hline $\begin{array}{c}\text { Friends in neighbourhood area advise me to choose Chinese } \\
\text { school }\end{array}$ & 3.17 & 1.34 & Moderately-High \\
\hline $\begin{array}{c}\text { I choose Chinese school because of suggestions from the } \\
\text { community prominent leaders }\end{array}$ & 3.02 & 1.29 & Moderately-High \\
\hline $\begin{array}{c}\text { Overall Mean } \\
\text { Tabreater }\end{array}$ & 2.98 & 0.52 & Moderately-Low \\
\hline
\end{tabular}

Table 2: Chinese School Selection Support for the Aspect of Family and Local Community

Based on table 2 above, the overall level for family and local community support is at only at moderately-low level with mean $=2.98$ and standard deviation $=0.52$. Item with highest mean score is following friends' influences with mean score $=3.25$ and standard deviation $=1.33$ which is at moderately-high level. Meanwhile, item with the lowest mean score (2.65) is preferring Chinese school because of neighbours' suggestions which is at moderately-low level.

\subsection{Chinese School Selection Support for the Aspect of School Reputation}

\begin{tabular}{|c|c|c|c|}
\hline Statement & Mean & Standard Deviation & Interpretation \\
\hline I choose Chinese school because of its academic excellence & 3.04 & 1.28 & Moderately-High \\
\hline I choose Chinese school because good pupils' discipline & 3.05 & 1.28 & Moderately-High \\
\hline $\begin{array}{c}\text { I choose Chinese school because of the school administration } \\
\text { competency }\end{array}$ & 2.94 & 1.29 & Moderately-Low \\
\hline I choose Chinese school because of suitable learning environment & 2.87 & 1.35 & Moderately-Low \\
\hline I choose Chinese school because of its curriculum achievement & 2.79 & 1.21 & Moderately-Low \\
\hline $\begin{array}{c}\text { I choose Chinese school because the teachers are committed in } \\
\text { teaching lessons }\end{array}$ & 2.90 & 1.29 & Moderately-Low \\
\hline $\begin{array}{c}\text { I choose Chinese school because the facilities provided are } \\
\text { adequate }\end{array}$ & 3.57 & 1.15 & Moderately-High \\
\hline $\begin{array}{c}\text { I choose Chinese school because of its tolerance towards other } \\
\text { ethnicities }\end{array}$ & 3.66 & 1.14 & Moderately-High \\
\hline I choose Chinese school because of its clear vision and aims & 3.68 & 1.12 & Moderately-High \\
\hline Overall Mean & 3.17 & 0.76 & Moderately-High \\
\hline
\end{tabular}

Table 3: Chinese School Selection Support for the Aspect of School Reputation 
Based on table 3 above, the overall level for Chinese school selection support from school reputation aspect is at moderately-high level with mean score $=3.17$ and standard deviation $=0.76$. Item that has the highest mean score $=3.68$ and standard deviation $=1.12$ is choosing Chinese school as it has clear and vivid goals. Meanwhile, the item with lowest mean score $=2.79$ and standard deviation $=1.21$ is preferring Chinese school due to its curriculum achievement which is only at moderately-low level.

\subsection{Chinese School Selection Support for the Aspect of Career Potential}

\begin{tabular}{|c|c|c|c|}
\hline Statement & Mean & $\begin{array}{c}\text { Standard } \\
\text { Deviation }\end{array}$ & Interpretation \\
\hline $\begin{array}{c}\text { I choose Chinese school because it may provide career } \\
\text { competition for my children }\end{array}$ & 3.68 & 1.12 & Moderately-High \\
\hline $\begin{array}{c}\text { I choose Chinese school because it may increase my Chinese } \\
\text { acquaintances that can help my children's career }\end{array}$ & 3.55 & 1.13 & Moderately-High \\
\hline $\begin{array}{c}\text { I choose Chinese school because of the advantages in } \\
\text { working environment that requires mandarin language }\end{array}$ & 3.47 & 1.31 & Moderately-High \\
\hline $\begin{array}{c}\text { I choose Chinese school as it may ease the process in } \\
\text { learning business strategies with Mandarin language }\end{array}$ & 3.37 & 1.31 & Moderately-High \\
\hline $\begin{array}{c}\text { I choose Chinese school as to give chances for my children to } \\
\text { engage with multi-ethnic friendsthat can expand their career } \\
\text { paths }\end{array}$ & 3.43 & 1.31 & Moderately-High \\
\hline $\begin{array}{c}\text { I choose Chinese school because the non-academic activities } \\
\text { focused more on pupils' talent, interest and abilities. }\end{array}$ & 3.71 & 1.15 & Moderately-High \\
\hline $\begin{array}{c}\text { I choose Chinese school because my children's discipline } \\
\text { may be improved as well as towards building good career } \\
\text { discipline }\end{array}$ & 3.51 & 1.33 & Moderately-High \\
\hline $\begin{array}{c}\text { I choose Chinese school because the competition in academic } \\
\text { and non-academic between the Chinese may foster positive } \\
\text { working culture }\end{array}$ & 3.50 & 1.35 & Moderately-High \\
\hline $\begin{array}{c}\text { I choose Chinese school because to preserve the } \\
\text { hardworking values since school period until working period }\end{array}$ & 2.88 & 1.31 & Moderately-Low \\
\hline Overall Mean & 3.46 & 0.84 & Moderately-High \\
\hline
\end{tabular}

Table 4: Chinese School Selection Support for the Aspect of Career Potential

Table 4 above shows the overall level for Chinese school selection support based $\mathrm{n}$ career potential is at moderately-high level with mean score $=3.46$ and standard deviation0.84. The highest mean score is item related to choosing Chinese school as the non-academic activities focused more on the children's talents, interests and abilities with mean score $=3.71$ and standard deviation 1.15. Meanwhile, the lowest mean score is item related to preserving the hardworking values from school period until working period.

\section{Discussions}

Every parents have the rights to choose the best school and education system for the sake of their children and the government is responsible in providing equal opportunities for every citizen (Ahmad \& Yusof, 2010).Descriptive analysis shows that the level of Chinese school selection support for the aspects of family and local community support are at moderately-low level. Meanwhile, from the aspects of school reputation and career potential are at moderately-high level. Choosing types of schools is always related to safety and home- (Kelly \& Scafidi 2013).

For the family and local community aspect, item with the lowest mean score is preferring Chinese school because of neighbours' suggestions which is at moderately-low level. Meanwhile, item with the highest mean score is following friends' influences which at moderately-high level. This clearly indicates that parents' selection is a part of the social process which is influenced by important social class categorization and social networks (Bosetti, 2004). Decision made by the parents are often the results of their personal values and education goals aimed to improve their children's potentials. Moreover, they also see for advices from acquaintances within the social and professional (Reynolds, 2005).

Descriptive analysis illustrates that the overall level of Chinese school selection based on school reputation is at moderately-high level. Item with the highest mean score refers to choosing Chinese school as it has clear and vivid goals. Meanwhile, the item with lowest mean score is preferring Chinese school due to its curriculum achievement which is only at moderately-low level. Nevertheless, among the reasons of choosing certain types of schooling is governed by school academic excellence, good attitudes among the school staff, schools that promote critical thinking skills, develop moral values and instil self-respect among the students (Bosetti 2004). The progressive demand for Chinese school is more prominent among Bumiputera students in Sabah dan Sarawak not only in the academic field but may also ignites concern pertaining to national unity (Mahathir, 2013).

Children's school selection is also one of the ways in parenting approach whereby the parents prefer to guide their children according to certain values, religion understanding and political views (Bethelsen \& Walker, 2004). Descriptive analysis shows that the overall level of Chinese school selection based on career potential is at moderately-high level. School selection is also associated motivation and school position in the job market and career prospects (Ahmad \& Yusof, 
2010). Item with the highest mean score is choosing Chinese school as the non-academic activities focused more on the children's talents, interests and abilities. Meanwhile, the lowest mean score is item related to preserving the hardworking values from school period until working period. This is due to higher chances of their children to pursue studies in high school following the values provided (Brasington \& Hite 2012). The norm of mingling around with Chinese friends may facilitate in shaping positive career potential (Lau et.al, 2012). Parents believe that the paths to further studies in China and Taiwan will be much easier by enrolling their children to Chinese schools (Aun \& Khalid, 2016).

\section{Conclusions}

This study provides insightful and positive implications for the school administrators and government to expand the children's potentials in many aspects including cognitive, affective, psychomotor that can be gained particularly through their schooling in Chinese schools. These positive changes not only applied in excellence academic results but also in co-curriculum achievements and high self-discipline as well as moral values instilled among the children.

\section{References}

i. Ahmad, Y. \&Yusof, N. M. 2010. Ethnic Boundary among students in Malaysian Primary Schools and Social Interaction: A Conceptual Framework. Procedia Social and Behavioral Sciences.

ii. Aun, L. H. \& Khalid, M. A. (2016) "Discrimination of high degrees: race and graduate hiring in Malaysia", Journal of the Asia Pacific Economy. 21 (1): 53-76.DOI:10.1080/ 13547860.2015.1055948.

iii. Bethelsen D. \& Walker S. 2008. Parents' involvement in their children's education. Family Matters 79. Australian Institute of Family Studies.

iv. Bosetti L. 2004. Determinants of school choice: understanding how parents choose elementary schools in Alberta. Journal of Education Policy. Vol 19, No 4.

v. Brasington, D.M. \& Hite, D. 2012. School choice and perceived school quality. economics letters.(116): 451-453.

vi. Kelly, J.P \&Scafidi, B. 2013. More than scores: an analysis of why and how parents choose private schools. the friedman foundation for education choice. indianapolis, november 2013.

vii. Lau, S.K., Ang L.H., Soon C.T., Law S. B \& Wong, N.L. 2012. Pengajaran dan pembelajaran bahasa cina dalam menggalakkan interaksi pelajar berbilang kaum. GEMA OlineTM Journal of Language Studies. ISSN:1675-8021. (3): 979-997.

viii. Reynolds, J. 2005.Parents' Involvement in their children's learning and schools: how should their responsibilities relate to the role of the state? Family \& Parenting Institute. Bristol, 2005

ix. Tan, Y.S. 2010. The education of ethnic minorities: the case of the Malaysian Chinese. Selangor: strategic information and research development centre. 